INTERNATIONAL FOOD

POLICY RESEARCH INSTITUTE

sustainable solutions for ending hunger and poverty

Supported by the CGIAR

IFPRI Discussion Paper 01009

July 2010

\title{
Do Household Definitions Matter in Survey Design? Results from a Randomized Survey Experiment in Mali
}

\author{
Lori Beaman
}

Andrew Dillon

Poverty, Health, and Nutrition Division 


\section{INTERNATIONAL FOOD POLICY RESEARCH INSTITUTE}

The International Food Policy Research Institute (IFPRI) was established in 1975. IFPRI is one of 15 agricultural research centers that receive principal funding from governments, private foundations, and international and regional organizations, most of which are members of the Consultative Group on International Agricultural Research (CGIAR).

\section{FINANCIAL CONTRIBUTORS AND PARTNERS}

IFPRI's research, capacity strengthening, and communications work is made possible by its financial contributors and partners. IFPRI receives its principal funding from governments, private foundations, and international and regional organizations, most of which are members of the Consultative Group on International Agricultural Research (CGIAR). IFPRI gratefully acknowledges the generous unrestricted funding from Australia, Canada, China, Finland, France, Germany, India, Ireland, Italy, Japan, Netherlands, Norway, South Africa, Sweden, Switzerland, United Kingdom, United States, and World Bank.

\section{AUTHORS}

Lori Beaman, Northwestern University

Assistant Professor, Department of Economics

Andrew Dillon, International Food Policy Research Institute

Postdoctoral Research Fellow, Poverty, Health, and Nutrition Division

\footnotetext{
Notices

${ }^{1}$ Effective January 2007, the Discussion Paper series within each division and the Director General's Office of IFPRI were merged into one IFPRI-wide Discussion Paper series. The new series begins with number 00689, reflecting the prior publication of 688 discussion papers within the dispersed series. The earlier series are available on IFPRI's website at www.ifpri.org/pubs/otherpubs.htm\#dp.

2 IFPRI Discussion Papers contain preliminary material and research results, and have been peer reviewed by at least two reviewers-internal and/or external. They are circulated in order to stimulate discussion and critical comment.
}

Copyright 2010 International Food Policy Research Institute. All rights reserved. Sections of this document may be reproduced for noncommercial and not-for-profit purposes without the express written permission of, but with acknowledgment to, the International Food Policy Research Institute. For permission to republish, contact ifpri-copyright@cgiar.org. 


\section{Contents}

Acknowledgments $\quad$ V

Abstract vi vi

1. Introduction 1

2. Background, Experimental Design, and Data 3

3. Results 9

4. Conclusion $\quad 18$

Appendix: Supplementary Table $\quad 20$

$\begin{array}{ll}\text { References } & 21\end{array}$ 


\section{List of Tables}

1. Concession-level outcomes $\quad 8$

2. Household size and composition 11

3. Assets 13

4. Food consumption $\quad 15$

5. Agricultural production and inputs 17

$\begin{array}{lr}\text { A.1. Descriptive statistics } & 20\end{array}$ 


\section{ACKNOWLEDGMENTS}

Funding from the Millennium Challenge Corporation (MCC) is gratefully acknowledged, along with the helpful assistance of Madeleine Gauthier and Annette Richter. Nouhoum Traore and Aissatou Ouedraogo provided excellent research assistance. We thank the editors, Kathleen Beegle, Kristen Himelein, three anonymous referees, seminar participants at the International Food Policy Research Institute, and conference participants at the Survey Design and Measurement Conference sponsored by the Enterprise Institute, Yale University, and the World Bank for insightful comments. These findings do not reflect the position or opinions of MCC. All errors are our own. 


\begin{abstract}
Household definitions used in multi-topic household surveys vary between surveys but have potentially significant implications for household composition, production, and poverty statistics. Standard definitions of the household usually include some intersection of keywords relating to residency requirements, common food consumption, and intermingling of income or production decisions. Despite best practices intending to standardize the definition of the household, it is unclear which types of definitions or which intersections of keywords in a definition result in different household compositions. This paper conducts a randomized survey experiment of four different household definitions in Mali to examine the implications for household-level statistics. This approach permits analysis of the trade-offs between alternative definition types. We find that additional keywords in definitions increase rather than decrease household size and significantly alter household composition. Definitions emphasizing common consumption or joint production increase estimates of the levels of household assets and consumption statistics, but not on per adult equivalency asset and consumption statistics, relative to open-ended definitions of the household. In contrast, definition type did not affect production statistics in levels, although we observe significant differences in per adult equivalency terms. Our findings suggest that variations in household definition have implications for measuring household welfare and production over time and across countries, as well as evaluation studies where the correct measure of spillover effects within and across households is necessary for measuring the benefits of an intervention.
\end{abstract}

Keywords: household definition, randomized experiment, assets, consumption, Mali 


\section{INTRODUCTION}

Household definitions used in multi-topic household surveys vary between surveys, but have potentially significant implications for household composition as well as statistics generated for household units. Standard definitions of the household usually include some intersection of keywords relating to residency requirements, common food consumption, and common intermingling of income or production decisions. Many explicitly require that the listing of persons cited as household members acknowledge a common household head. Despite best practices to standardize the definition of the household, it is unclear which types of definitions or which intersections of keywords in a definition result in differences in household composition or size. More problematic, the reported household listing may not capture the relevant economic unit, and that could bias household statistics such as consumption aggregates, assets, or household production. Although different household definitions may be used to address different economic units of interest, it is unclear whether comparing results from surveys using different definitions would affect empirical analysis. Further comparisons within countries over time or across countries may be biased if alternative household definitions were used when collecting the data. The existence or extent of biases is difficult to assess, however, as there is no rigorous evidence on how sensitive household statistics are to the chosen definition.

We investigate this question using a survey experiment in rural Mali, where four recent national surveys used four different household definitions, resulting in varying reported household sizes from 5.7 to 9.1. Most households in rural Mali, like in many developing country contexts, depend on subsistence agriculture, and households live in close proximity to extended family members in shared family compounds. Given the rather complex structure of household arrangements in Mali, it is an excellent setting to examine whether measures of household structure, assets, food consumption, and agricultural production are sensitive to the definition of the household used in a standard household survey. The problem of correctly classifying individuals into household units is a problem that may be particularly acute in societies where extended families cohabitate together in shared family compounds.

The paper conducts a randomized survey experiment of four different household definitions to examine the implications for household statistics. This approach permits analysis of the trade-offs between alternative definition types. ${ }^{1}$ We chose to vary definition types by adding or removing specific conditions or keywords commonly used in the household definition to test the effect of those requirements on household composition and statistics. The first definition requires only that members of the household live in the same lodging and acknowledge a common household head. The second includes the criteria of the first definition but adds the criterion that households eat commonly prepared food together. The third definition includes the criteria from the first definition and adds the stipulation that members must work together on at least one agricultural plot or in one revenue-generating activity. The fourth definition combines the eating and production requirements of the second and third definitions with the criteria from the first definition.

We find that different household definitions have significant implications for household composition as well as for assets and consumption statistics. In particular, household size changes when common income-generating and production keywords (Definition 3) are added to an open-ended definition (Definition 1). We also find variation in household composition even among definition types that have no effect on total household size. Each of Definitions 2, 3, and 4 leads to more prime-aged adults reported within the household, relative to Definition 1. In particular, the number of married brothers and married sons within the household also varies by household definition. This suggests that

\footnotetext{
${ }^{1}$ Fundamentally, we do not know what the "true" household size is when comparing alternative definitions, or whether in extended cohabitating families, members can be assigned into "true" households, since the criteria of economic production and mutual production of public goods that define an economic household become blurred.
} 
how "nuclear" conjugal units are combined into a household is sensitive to the formulation of the household definition. ${ }^{2}$

These changes in household size and structure have consequences on household statistics, especially those statistics that are paramount to the measurement of household welfare. Household asset holdings are higher in Definition 3 households: on average, such households have 0.3 of a standard deviation more of common agricultural items, 0.2 of a standard deviation of additional animals, and 0.2 of a standard deviation more of nonfarm household durable goods. Households asked to use the common consumption definition (Definition 2) also report more livestock holdings. However, there is little evidence that per adult equivalency measures of assets vary by household definition. An emphasis on common food consumption in Definition 2 leads to reports of higher consumption of grains in the last seven days. These patterns are largely consistent with an increase in household size and the change in the composition of the household altering measured assets, livestock, and consumption figures.

We do not observe differences across the definitions for the levels of agricultural production and inputs, but do note that production statistics measured in per adult equivalents differ significantly for Definition 4 relative to Definition 1. The fact that per adult equivalency measures are sensitive to household definition for some outcomes of interest suggests that both changes in household size and composition drive differences across the consumption, asset, and production modules and that respondents do not "scale" their responses uniformly across the different modules. This may be due to asymmetric information among household members as consumption and asset holdings may be relatively more observable when food is consumed and assets stored in common, while agriculture may be decentralized across multiple plots by several different decisionmakers. Alternatively, differences in recall periods across the modules could also affect measurement.

The choice of household definition used in a survey may be particularly important in an environment such as Mali, where people live in compounds. Although this is common in West Africa, potential ambiguities may arise in other settings with multigenerational or extended families. Therefore, the next section provides a background on the existence of complex household structures in many lowincome societies around the world. Nevertheless, the lessons from this survey experiment are particularly relevant for household surveys conducted in Sub-Saharan Africa, particularly West Africa.

The rest of the paper is organized as follows: in the second section, we also provide some background on household structure in Mali, including a description of previous household definitions used in prominent Malian surveys that motivated our choice of definitions in this study. The study design and the data collected to conduct this experiment are also described in this section. In the third section, we present our results. The last section concludes with a more detailed discussion of the implications of this experiment for future household surveys.

\footnotetext{
${ }^{2}$ Another important question is whether everyone in the village is counted under each definition - that is, whether a change in the definition of the household just reallocates individuals into different households or whether some definitions leave out individuals altogether. Since the survey experiment randomized the definition at the household level and there are no reliable population figures for these villages, we unfortunately cannot address this question.
} 


\section{BACKGROUND, EXPERIMENTAL DESIGN, AND DATA}

\section{Background and Context}

Whereas the most commonly used definition of the household is one that relates to the notion of consumption from the "common pot," there are a range of ambiguities related to the definition in almost all country contexts. These include problems of classification related to residency requirements, kinship, and the differentiation between income contributions to the common pot and informal social insurance, such as transfers between family members. Part-time residents, boarding students, temporary migrants, and domestic help are categories of potential household members that are difficult to categorize, but whose classification as household members is often determined by duration of residency and financial contribution of income for the household's expenditures. Despite best-practice recommendations on the classification of some types of individuals, extended kinship ties and relevant economic definitions of the household have often been critiqued by economic anthropologists whose detailed ethnographies document the multiple and interlinked family, social, and economic relationships among people. Jane Guyer's (1981) work demonstrates how "'lineage' and 'household' as concepts share the problem of designating complex collectivities as units," particularly in Africa. She also points out that the study of household vulnerability in agriculture may be sensitive to how the household is constructed, particularly in the context where substantial flows of resources occur within and across households. Her work serves as motivation for this study's objective of looking at how household measures of assets, consumption, and agriculture may be sensitive to the choice of the household definition. Furthermore, Polly Hill (1986) has argued, more forcefully, that common production is an essential element of the household definition and has questioned the very idea that there can be a common household definition that would apply to all contexts.

In fact, many early recommendations by anthropologists have become incorporated into economic household surveys as they have evolved, despite the inevitability that definitions need to be standardized to conduct large-scale surveys. In their recommendations, Glewwe and Grosh $(2000,135)$, citing a United Nations (1989) study, note, "For the purposes of conducting a household survey, the standard definition of a household is a group of people who live together, pool their money, and eat at least one meal together each day." Nevertheless, they remark in a footnote that sufficient flexibility should be incorporated in the definition to adapt to local context. The ambiguity of the definition of a household is particularly acute in many African settings. Economists increasingly confront these concepts in their household surveys, acknowledging that households are flexible and fluid. A small but important literature investigates the economic implications of the heterogeneity of household structures. ${ }^{3}$

In the Segou region of Mali, the context for this study, household structure is complex-as it is in many parts of the world. Individuals exchange resources among multiple types of familial and social relationships. Oftentimes, a household lives in proximity to members of its extended family within a common area, called a compound or concession, enclosed by a single wall. Food preparation, sanitation, and dwelling maintenance tasks may be undertaken jointly within the concession, and economies of scale in production are exploited. Two essential aspects of economic decisionmaking are food preparation and agricultural production, and we discuss each in turn. First, with respect to food consumption, individuals live in households that share concessions where food production may be centralized, at least for certain meals. The division of labor is gender-based, and women may have use rights over multiple granaries, including a household and central concession granary, from which they may draw grain to prepare common meals. Men may contribute to their own granaries and have obligations to contribute grain to communal granaries. With respect to production, a group of family members may work together on

\footnotetext{
${ }^{3}$ For example, Akresh (2009) investigates the effects of child fostering across households along kinship lines in Burkina Faso. Hosegood and Timaeus (20051) investigate how household composition has changed over time in South Africa. From a more methodological perspective, Christiaensen and Hoddinott (2001) compare the effect of rapid appraisals and communitybased listing exercises on household size and village population with updated census information.
} 
common familial lands, but the division of common plot harvests into individual granaries varies from family to family. Many families prepare their food separately out of these reserves, whereas some completely store and consume the harvest communally. These complexities make identifying one definition for the household difficult: there are ethnic differences that generate differences in norms, but also family-specific heterogeneity in the costs and benefits of aggregate living and preferences over household structure.

This problem is certainly not unique to Mali. Matlon (1988) remarks the following in reference to the frequently used ICRISAT (International Crops Research Institute for the Semi-Arid Tropics) data from Burkina Faso:

An entirely unambiguous, consistent, and universal definition of the "household" for use in sampling, data collection and analysis, proved to be elusive.... As a working definition we defined the household as the smallest group of persons usually, but not exclusively kin related who form a more or less independent production and consumption unit during the cropping season. To operationalize this definition we set two conditions based on observed group behavior and consistent with farmers' own criteria for defining households: first, that members of the household work jointly on at least one common field under the management of a single decisionmaker, and second, that members draw an important share of their staple foodstuffs from one or more granaries which are under the control of that same decision-maker. Because both of these criteria sometimes tended to vary in a continuous rather than discrete manner, for [ambiguous] individuals the final boundaries used to delimit household from nonhousehold members were drawn by the household heads themselves.

Indeed, evaluating whether a "household" reaches Pareto efficiency depends critically on who is considered a household member according to the definition of the household chosen. Udry (1990) also references the difficulty in choosing an appropriate unit of analysis in northern Nigeria, while Van de Walle and Gaye (2005) describe the complex household structure in Senegal and The Gambia. In their work, they describe how the censuses in the respective countries have attempted to capture that complexity. In Senegal, the census enumerates concessions, then households, and then nuclear units.

Although acute, the difficulty in determining household membership is not limited to West Africa. In Tanzania, a mixed-method survey has suggested that household structure is complicated and varies by region within Tanzania, and that the 2004 Demographic and Health Survey definition - with its emphasis on residency and a common source of food - is often inconsistent with the "true" household as determined by in-depth interviews (Leone, Coast, and Randall 2009). ${ }^{4}$ Muga and Onyango-Ouma (2009) describe how the Luo people of western Kenya live in homesteads where multiple generations cohabit, although the extended family is shrinking over time. Hill (1986) suggests that the determination of the household head is difficult even in southern India.

In low-income societies, some demographers have posited a positive relationship between lowerincome and multigenerational household structures, although exceptions exist (Vimard and Fassassi 2005; Ruggles and Heggeness 2008). This makes the relevant economic unit challenging, as it may change over time and with economic development. In income-poor settings, nonnuclear household structures benefit from larger size and economies of scale in market and domestic production activities. For example, Saito (2000) describes extended family households in preindustrial Japan where two generations of nuclear households lived together in the same compound. After the industrialization, however, there are few incidences of this household structure. Complex household arrangements continue in other parts of Asia: Bryant (1996) describes contemporary differences between northern and southern Vietnamese household structure related to differences in intergenerational residency norms. However, there is a debate in the demographic literature whether extended family structures — such as intergenerational residency — have

\footnotetext{
${ }^{4}$ The study focused on three areas with particularly challenging populations in terms of the concept of the household: Longido (primarily Maasai), urban Dar es Salaam, and Rufiji in the south. They also find household sizes that are similar to those we find in Mali: average household size is much smaller using the standard DHS Definition (5.86) compared to household size estimated using the mixed method approach (11.23).
} 
been stable or increasing over time, particularly in a sample of Latin American countries (Ruggles and Heggeness 2008).

As mentioned previously, four recent national surveys in Mali have used different household definitions. The Demographic and Health Survey (DHS) of Mali 2006 uses the following definition: "Please list the names of the people who normally live in your household and the visitors who passed the last night here, beginning with the head of household" (Samaké et al. 2007). The Rapid Household Survey (RHS) 2006 uses the following, more extensive definition: (translated by the authors into English) (Mali 2007):

A household is a group of people who normally live and eat their meals together in the household. Members must acknowledge the authority of one person as head of household and that person must actually live with the rest of the household members.

In polygamous households, each wife is treated as a distinct household when the wives live in different houses, cook separately and take decisions independently.

... The household is an economic unit in which the members possess certain economic ties. They may participate together in the same productive activity, earning income together. The survey permits the use of all information which includes key events which illustrate this type of economic behavior. It is essential that all people who participate in the decisions or are affected by the results of these decisions are included in the household.

For official population measures, the Malian Census in 1998 and 2008 used the following definition:

The household is a group of persons related or not, living under the same roof, under the responsibility of a head whose authority is acknowledged by all the members. The ordinary household is composed of a head of household, his spouse(s), his unmarried children, and possibly his relatives or other persons to whom he is unrelated. The household can be limited to only one person or a person with his children.

Particular cases:

1. In a polygamous household where all the spouses do not live in the same concession as their husband, each of the spouses living elsewhere will be listed as a separate household with the persons they live with (the spouse being the head of that household).

2. A tenant who does not take his meals where he lives is considered as a separate household.

3. In a case where a man lives in a concession with his spouse(s) and his children among which some are married, each of the married sons with his spouse(s), his children, and other unmarried dependents under his responsibility will form a separate household.

4. In a group of unmarried people living together where everyone has his own means of livelihood, each member of the group will form his own household.

Both of these definitions include the idea that a household eats together and has shared productive activity. However, these concepts are applied in a potentially ad hoc manner in only some settings. For example, a tenant is considered separate if he eats meals separately, but a group of unmarried individuals living in the same residence are separate households if they each earn their livelihood together. In the DHS, individuals undertaking the same productive activity "may" constitute a household. The Census attempts to delineate extended families into separate households (particular case 3), while the DHS and the RHS are more open to interpretation. 
The Demographic and Health Survey reports an average size of 5.7, while the Rapid Household Survey 2006 reports an average household size of 8.5, and 9.1 in the region of Mali we study. ${ }^{5}$ Official statistics for the 2008 Malian Census have not been released to date. Although the surveys are not perfectly compatible in all other aspects, particularly sampling methodology, the differences in measured household size may be at least partly due to the different household definitions. Variation in requirements of household membership, keywords included in the definition, or even the sequencing of those keywords could potentially influence the respondent in organizing the list of people included in a household roster. The economic concept of the household, as in other contexts, may therefore not intersect perfectly with the social concept of the family or with any one definition of a household. The complexities in Malian household structure and observed differences in household sizes motivated our interest to test the consequences of using different definitions on household statistics. ${ }^{6}$

\section{Experimental Design}

To test differences in definition types on household composition, consumption, and production, we created four different definitions that focus on keywords relating to two of the key factors often found in household definitions - namely, common food-sharing requirements and common agriculture or incomegenerating activity requirements. The inclusion or exclusion of these criteria creates four different definitions. In our experimental approach, we randomly vary including common food requirements and/or joint agricultural or other income-generating requirements in administering a standard questionnaire. This yields four definitions. The first definition is open-ended with only the requirement that all members acknowledge the same household head and live in the same dwelling space. The second and third definitions impose one of the two requirements, either common food or common agriculture and income generation. The fourth definition is the combination of both requirements.

Enumerators were given instructions to read the randomly allocated definition to respondents. ${ }^{7}$

Each enumerator administered each definition in every village they surveyed. The definitions were translated into local languages, and enumerators were tested on their understanding of the definition before the fieldwork commenced. Here are the definitions, ${ }^{8}$ translated into English, with the key differences between them italicized here only for exposition:

\footnotetext{
${ }^{5}$ While not a household survey per se, the Malian Agricultural Census of 2005 uses the FAO recommended Definition of an agricultural holding, which states: "An agricultural holding is an economic unit of agricultural production under single management comprising all livestock kept and all land used wholly or partly for agricultural production purposes, without regard to title, or legal form of households. Single management may be exercised by an individual or household jointly by two or more individuals or households, by a clan or tribe, or by a juridical person such as a corporation cooperative or government agency" (Mali 2006). Households are then defined implicitly through this Definition of an agricultural holding and sampling units are determined by households and not by plots of land. The 2005 Agricultural Census reported an average household size of 6.

${ }^{6}$ Using different definitions is not unique to Mali. In Côte d'Ivoire, the government has used different household definitions over time. The following are examples of household definitions used as described in Vimard and Fassassi (2005). In 1975 and 1988, the following Definition was used: to define the household as "the group of persons, related or not, who acknowledge the authority of one individual entitled 'head of household' and who hold part of their resources in common. They live in the same building." In 1998, the Definition was altered such that the household was defined as "a group of persons who sleep usually in the same dwelling and who have shared their meals during three months at least during the 12 months that preceded the interview."

${ }^{7}$ The following instructions were given to each enumerator and listed on the cover page of each questionnaire: "At the beginning of the interview, read the following Definition to the head of household and other household members present. For the purposes of this interview, take the following Definition as the Definition of the household." Enumerators were paid a daily rate and were not incentivized by payment per questionnaire completed. Enumerators undertook a three-day training course led by the authors to ensure comprehension of the 13-page questionnaire, with an emphasis on comprehension and memorization of the household definitions. A piloting exercise was conducted after enumerator training to test the questionnaire and enumerator quality. We check for potential enumerator biases in our estimates by including enumerator indicators in our specifications as a robustness check. The inclusion of such variables does not alter our results, which are available upon request.

${ }^{8}$ Although not explicitly stated, the household Definition normally refers to the set of adults that should be included in the household, after which their children are accounted. Children are ascribed to a household if the adults in that household have primary caretaking responsibility.
} 
Definition 1: A household is composed of the group of people living in the same dwelling space and who acknowledge the authority of a man or woman who is the head of household.

Definition 2: A household is composed of the group of people living in the same dwelling space who eat meals together and acknowledge the authority of a man or woman who is the head of household.

Definition 3: A household is composed of the group of people living in the same dwelling space who have at least one common plot together or one income-generating activity together (for example, herding, business, or fishing) and acknowledge the authority of a man or woman who is the head of household.

Definition 4: A household is composed of the group of people living in the same dwelling space who eat meals together and have at least one common plot together or one incomegenerating activity together (for example, herding, business, or fishing) and acknowledge the authority of a man or woman who is the head of household.

In many household definitions, the idea of "co-mingling" of incomes is used instead of explicitly requiring common productive activities as we did in Definitions 3 and 4. We felt this definition was clearer, easy to translate into the local language, similar in spirit to the "same productive activity" used in the RHS, and fit well with the setting, since the vast majority of households undertook farming where almost all household members (including children) contribute to the farming effort. Note that we will often refer to common income generation as common agriculture in the subsequent sections of the paper.

The definition of the household was randomized within each village at the finest sampling unit. In particular, since dwellings are organized into concessions, the definition was randomly assigned to sampled concessions. When an enumerator entered the concession, he or she would speak to the head of the concession and read the selected household definition. Using that definition, the enumerator would write down a list of household heads within that concession and then randomly select one. ${ }^{9}$ An equal number of household definitions were allocated among the concessions selected per village.

The sampling frame of villages was developed based on the latest available census data in Mali, the Recensement Generale du Population 1998, ${ }^{10}$ and updated by local government officials for the purpose of this and a related study. Since the randomized survey experiment was conducted as part of a pilot for an evaluation of a large-scale irrigation project, the sample was divided into three strata within the sampling universe, which included all villages in the administrative units, called cercles (Macina, Niono, and Segou), in the region of Segou. The three strata include a subsample of the intervention zone called the Alatona, those villages with access to a large-scale irrigation scheme in the Office du Niger, ${ }^{11}$ and those with only rainfed plots in the three cercles. Ten villages were randomly selected in the Alatona strata. Twenty-two villages were randomly selected in the Office du Niger strata and 24 villages in the periphery groups, with up to 20 concessions selected per village. ${ }^{12}$ All villages were selected with probability proportional to size.

Without a list of individuals within sampled villages, concessions were chosen using a circular sampling technique, where enumerators started at a common location in the village and were randomly assigned a household definition to start with. The survey instruments were designed with a common set of core modules on household composition, assets and livestock holdings, agricultural production and inputs, and food consumption.

\footnotetext{
${ }^{9}$ The random selection of households within selected concessions implies that households who reside in large concessions are underrepresented. Therefore, to compute village-level statistics, the observations would need to be reweighted to correct for this sampling method.

${ }^{10}$ The census information is summarized in the software package Cartographie du Mali 1998, distributed by the government of Mali, Mission for the Decentralization, produced by Fox Media, and financed by UNICEF (Mali 1999).

${ }^{11}$ The Office du Niger was originally constructed in 1932 as a gravity irrigation scheme during French colonialism. Since Malian independence, the government of Mali has managed the system.

${ }^{12}$ Some of the villages are very small, and there were not 20 concessions in the village.
} 
Despite the fact that definitions were allocated randomly to households, most field experiments verify empirically that there are no differences between treatment and control households along observable characteristics. In our experiment, the household and descriptive statistics of the household are the very object of our analysis. The nature of the treatment is that all characteristics collected in the household survey are endogenous. We collected one measure at the concession-level, the number of granaries-which is presented in Table 1 . Concessions ${ }^{13}$ are a physical space defined by an outer wall, observable by all, and not subject to the definition of the household. When we compare the number of granaries found in the household's concession, no significant variation exists between the four definition types. That is consistent with the randomization generating balance across treatment and control, although this one result is, of course, far from a full randomization check. The results of the experiment are described in the next section.

Table 1. Concession-level outcomes

\begin{tabular}{|c|c|c|}
\hline & (1) & (2) \\
\hline & $\begin{array}{l}\text { Number of granaries } \\
\text { in concession }\end{array}$ & $\begin{array}{c}\text { Number of households } \\
\text { per concession }\end{array}$ \\
\hline Definition 2: common food, dwelling, authority & $\begin{array}{c}0.023 \\
(0.075)\end{array}$ & $\begin{array}{c}0.041 \\
(0.054)\end{array}$ \\
\hline Definition 3: common agriculture, dwelling, authority & $\begin{array}{c}0.082 \\
(0.075)\end{array}$ & $\begin{array}{c}0.074 \\
(0.054)\end{array}$ \\
\hline Definition 4: common agriculture; common food, dwelling, authority & $\begin{array}{c}0.010 \\
(0.075)\end{array}$ & $\begin{array}{c}0.043 \\
(0.054)\end{array}$ \\
\hline Constant & $\begin{array}{l}1.347 * * * \\
(0.053)\end{array}$ & $\begin{array}{l}1.110^{* * *} \\
(0.038)\end{array}$ \\
\hline p-value: joint test of Definition 2, Definition 3, and Definition 4 & 0.697 & 0.593 \\
\hline Number of observations & 1,018 & 1,020 \\
\hline
\end{tabular}

Notes: The omitted definition is Definition 1: common dwelling and authority. All regressions include village fixed effects. $* * * \mathrm{p}<0.01, * * \mathrm{p}<0.05, * \mathrm{p}<0.1$

\footnotetext{
${ }^{13}$ Concession is the term used in Mali, so we retain it for the purposes of this paper. In English, it is equivalent to compound or homestead.
} 


\section{RESULTS}

All results are shown using the following specification:

$$
y_{i j}=\beta_{0}+\beta_{2} \operatorname{Def}_{i j}+\beta_{3} \operatorname{Def}_{i j}+\beta_{4} \operatorname{Deft}_{i j}+\delta X_{j}+\varepsilon_{i j},
$$

where Def2,Def3, and Def4 are indicators for the definitions used in the interview of household $i$ in village $j$ : Definition 2, Definition 3, and Definition 4 as defined earlier under "Experimental Design." Definition 1, the open-ended definition that requires only common residency and acknowledgment of a household head, is the excluded definition. Coefficients are naturally interpreted as the consequence of adding additional keyword restrictions on the household listing. $X_{i j}$ are village-level indicators to control for unobservable village characteristics ${ }^{14}$ such as differences in rainfall, farming systems, ethnicity, or access to infrastructure across villages. ${ }^{15}$ Summary statistics of the key variables across definition types are reported in Appendix Table A.1.

In the following, we investigate differences across household definitions in four key variable categories: household composition, assets and livestock holdings, food consumption, and agricultural production.

\section{Household Composition}

Table 2 presents our results on household composition. In our analysis, we report household size for members of the household who are resident at least six months ${ }^{16}$ and disaggregate household composition into the number of adults, the number of married men, number of married women, number of married adult sons of the household head, and number of married brothers as reported by the household head.

Household sizes vary across the definitions between 11 and 12 persons, on average, which is rather large but not unexpected in this area of Mali. In column (1) in Table 2, we find that the effect of adding a common agricultural requirement to the household definition increases the number of persons listed in the household by one household member. This constitutes an increase of 0.17 of a standard deviation. Initially, we expected that an open-ended definition would produce larger household sizes since we anticipated that the criteria in Definitions 2 through 4 would put restrictions on household membership. However, additional keywords prompted respondents to increase the number of members listed in the household in comparison to the first, open-ended definition, although not all increases in household size are statistically significant. We interpret this as meaning that keywords ultimately prompt respondents to (1) include people who fit the criteria who may have otherwise been forgotten and/or (2) report an alternative grouping of people as the household. In an environment where overlapping groups of people eat together and engage in common income-generating activities, both interpretations are consistent.

In addition to the effect of definition type on total household size, variation in the composition of the household is also significantly affected by alternative definitions. Altering definitions in our household survey altered household composition, even for definitions where we did not observe precisely estimated increases in total household size. Column (3) shows increases in the number of adults aged 1660 , from 0.6 to 0.9 individuals, for all definition types relative to the open-ended definition. In results not shown, no statistically significant increases in the number of children under 16 or females were found, nor

\footnotetext{
${ }^{14}$ We also conducted analysis including enumerator indicators and day-of- the-week indicators to control for potential unobservable variation across enumerators or the day of the week that an interview is taken. The results reported in this paper are robust to these those additional specifications, and we omit them for brevity. These results are available upon request.

${ }^{15} \mathrm{We}$ also conducted analysis including enumerator indicators and day-of-the-week indicators to control for potential unobservable variation across enumerators or the day of the week that an interview is taken. The results reported in this paper are robust to these additional specifications and we omit them for brevity. The results are also similar without village fixed effects. These results are available upon request.

${ }^{16}$ Our results are robust to differing residency requirements, so we report this frequently used measure of household size with a six-month residency requirement.
} 
in the number of adults over the age of 60 . Changes in the number of married men in a household represent a qualitative change in household structure. More married men within a household increases the complexity of decisionmaking and resource allocation within the household, as Malian men officially control and allocate their own resources not only for their wives and children, but in coordination with other married men to provide household public goods. Columns (4) and (5) of Table 2 show that definitions emphasizing common agriculture-Definitions 3 and 4-result in a larger number of married men and women within the household. In agricultural households where members of certain families have use rights over common agricultural lands and the continuum of production and consumption responsibilities overlaps such as in our sample, keywords in the definition of the household may cause the reorganization of family members into households.

To investigate household structure further, columns (6) through (9) of Table 2 look at the types of marriage and cooking arrangements. Multiple married men within a household may arise if a household head lives with his adult married son(s) or if married brothers share one household. Column (6) suggests that common food consumption leads to an increase in the number of generations present within a household. The dependent variable is an indicator for one or more adult married sons of the household head who reportedly live in the household. Definition 2 results in a 9-percentage point increase in the likelihood that the household is multigenerational. ${ }^{17}$ Since 33 percent of Definition 1 households had at least one married son of the head as a member, Definition 2 prompted a 28 -percent increase in incidence of multigenerational households reported. A household definition that emphasizes common agriculture generates households with multiple married men of the same generation. In column (7), we see that Definitions 3 and 4 result in an 8-percentage point increase in the probability that multiple married brothers are considered as one household. Therefore, although there is only weak evidence that the total number of married men varies across definition, a more detailed analysis reveals that each definition $(2,3$, and 4) reveals a distinctive type of household. As discussed previously in the background section, the tradition in this part of Mali is for all married sons to remain in the household of their fathers or for brothers to remain as one household, sharing a common granary and farming the family land jointly. These results are suggestive that different household definitions may identify different economic units within the same extended family. For example, there may be a subset of an extended family that undertakes common food consumption, while another subset may act as a common unit for agricultural production. Varying the household definition by emphasizing one type of activity (food consumption or a productive activity) may solicit a listing of household members based on who undertakes that activity together, which then generates both differences in household size and structure as measured by the household roster.

${ }^{17}$ Since the custom in Mali is that men stay in their natal village/household and women are married off into other households, we focus here only on the number of married men. 
Table 2. Household size and composition

\begin{tabular}{|c|c|c|c|c|c|c|c|c|c|}
\hline & $(1)$ & (2) & (3) & (4) & (5) & (6) & (7) & (8) & (9) \\
\hline & $\begin{array}{c}\text { Total } \\
\text { household } \\
\text { size: Resident } \\
\text { for last } 6 \\
\text { months }\end{array}$ & $\begin{array}{l}\text { Age of } \\
\text { household } \\
\text { head }\end{array}$ & Adults $16-60$ & $\begin{array}{l}\text { Number of } \\
\text { married } \\
\text { men }\end{array}$ & $\begin{array}{l}\text { Number of } \\
\text { married } \\
\text { women }\end{array}$ & $\begin{array}{c}1 \text { or more } \\
\text { adult married } \\
\text { sons (of } \\
\text { household } \\
\text { head) }\end{array}$ & $\begin{array}{c}1 \text { or more } \\
\text { adult married } \\
\text { brothers (of } \\
\text { household } \\
\text { head) }\end{array}$ & $\begin{array}{l}\text { Share meal } \\
\text { preparation }\end{array}$ & $\begin{array}{c}\text { Cook } \\
\text { independently }\end{array}$ \\
\hline $\begin{array}{l}\text { Definition 2: common food, } \\
\text { dwelling, authority }\end{array}$ & $\begin{array}{c}0.780 \\
(0.506)\end{array}$ & $\begin{array}{l}2.13^{*} \\
(1.20)\end{array}$ & $\begin{array}{l}0.631 * * \\
(0.295)\end{array}$ & $\begin{array}{c}0.212 \\
(0.136)\end{array}$ & $\begin{array}{c}0.225 \\
(0.157)\end{array}$ & $\begin{array}{l}0.092 * * \\
(0.043)\end{array}$ & $\begin{array}{c}0.040 \\
(0.035)\end{array}$ & $\begin{array}{c}0.056 \\
(0.040)\end{array}$ & $\begin{array}{c}0.028 \\
(0.056)\end{array}$ \\
\hline $\begin{array}{l}\text { Definition 3: common } \\
\text { agriculture, dwelling, authority }\end{array}$ & $\begin{array}{l}1.060 * * \\
(0.507)\end{array}$ & $\begin{array}{l}2.19^{*} \\
(1.20)\end{array}$ & $\begin{array}{l}0.852 * * * \\
(0.296)\end{array}$ & $\begin{array}{c}0.258^{*} \\
(0.136)\end{array}$ & $\begin{array}{l}0.378^{* *} \\
(0.158)\end{array}$ & $\begin{array}{c}0.034 \\
(0.043)\end{array}$ & $\begin{array}{l}0.080^{* *} \\
(0.035)\end{array}$ & $\begin{array}{l}0.096 * * \\
(0.040)\end{array}$ & $\begin{array}{l}0.130^{* *} \\
(0.056)\end{array}$ \\
\hline $\begin{array}{l}\text { Definition 4: common } \\
\text { agriculture; common food, } \\
\text { dwelling, authority }\end{array}$ & $\begin{array}{c}0.715 \\
(0.507)\end{array}$ & $\begin{array}{l}2.93^{* *} \\
(1.20)\end{array}$ & $\begin{array}{l}0.551 * \\
(0.296)\end{array}$ & $\begin{array}{l}0.262 * \\
(0.136)\end{array}$ & $\begin{array}{l}0.300 * \\
(0.158)\end{array}$ & $\begin{array}{c}0.064 \\
(0.043)\end{array}$ & $\begin{array}{l}0.084 * * \\
(0.035)\end{array}$ & $\begin{array}{c}0.056 \\
(0.040)\end{array}$ & $\begin{array}{l}-0.006 \\
(0.056)\end{array}$ \\
\hline Constant & $\begin{array}{l}11.006^{* * *} \\
(0.357)\end{array}$ & $\begin{array}{l}52.43 * * * \\
(0.85)\end{array}$ & $\begin{array}{l}5.391 * * * \\
(0.209)\end{array}$ & $\begin{array}{l}1.902^{* * *} \\
(0.096)\end{array}$ & $\begin{array}{l}2.327 * * * \\
(0.111)\end{array}$ & $\begin{array}{l}0.331 * * * \\
(0.030)\end{array}$ & $\begin{array}{l}0.156^{* * *} \\
(0.025)\end{array}$ & $\begin{array}{l}0.552^{* * *} \\
(0.028)\end{array}$ & $\begin{array}{l}0.313 * * * \\
(0.041)\end{array}$ \\
\hline $\begin{array}{l}\text { p-value: joint test of Definition 2, } \\
\text { Definition 3, and Definition } 4\end{array}$ & 0.190 & 0.086 & 0.030 & 0.173 & 0.094 & 0.164 & 0.059 & 0.115 & 0.045 \\
\hline $\mathrm{N}$ & 1,021 & 1,021 & 1,021 & 1,021 & 1,021 & 1,021 & 1,021 & 1,016 & 608 \\
\hline
\end{tabular}


A specific example of the complexities of household structure is that food preparation may be shared within a household or a concession for at least some meals. Traditionally in Mali, when multiple married couples constitute the same "household," women take turns in cooking food for the entire group. We therefore ask whether differences in household definitions would increase variation in the types of food preparation practices households report. Columns (8) and (9) of Table 2 investigate how meal preparation is organized within the household and whether the cooking arrangement varies systematically with household definition. Column (8) presents estimates from a linear probability model in which the dependent variable is an indicator for whether the main female respondent reports that she shares the responsibility of meal preparation for the household with another woman. We see that households that were randomly assigned Definition 3 are significantly more likely compared with the open-ended definition to have multiple women within the same household sharing the duty of meal preparation. This result suggests that an emphasis on common agriculture, as in Definition 3, leads to reported households with more complex structures. Column (9) presents results, conditional on sharing meal preparation, that the main female respondent also cooks for a subgroup of people within the "household" when another woman is responsible for cooking for the larger unit. Although we need to be cautious in interpreting these results, since they are conditional on sharing meal preparation that is endogenous to the household definition used, we see that respondents assigned Definition 3 are more likely to report cooking independently within the shared meal preparation setting. We interpret this as evidence that an emphasis on a common income activity in particular generates reported households in which there is some autonomous decisionmaking that occurs within the larger household structure. It also highlights how the "common pot" definition can potentially be too vague if some but not all meals are consumed together, which is likely to occur in many settings.

Another complexity of household structure is polygamous relationships within families and households. Polygamy is frequent in our sample with 39 percent of households reporting that the household head practices polygamy. Variations in definition phrasing may screen out polygamous household members, classifying them as separate households or as a single household, depending on the criteria included in the definition. In our estimates of the effect of definition type on household composition, we find no statistically significant differences in the percentage of households reporting polygamy across definitions. We also do not find any effect of household definition on the likelihood that a household is female-headed ${ }^{18}$ or on the variability of household size, as captured by the standard deviation of household size. There is weak evidence that Definition 3, emphasizing common agriculture or a common economic activity, resulted in a higher percentage that the household included at least one farmer relative to Definition 2, and that Definition 2, focusing on consumption, increased the likelihood of at least one herder or fisherman in the household in comparison to the open-ended Defintion1. Results not reported in this paper are available from the authors upon request.

\section{Assets}

Table 3 shows the relationship between definition type and farm assets, livestock holdings, and nonfarm assets both in levels and per adult equivalents. ${ }^{19} \mathrm{We}$ find significant increases in the farm and nonfarm asset indexes in levels among households assigned a definition with a common agriculture requirement, and increases in livestock holdings among Definition 2 and 3 households. The effect of Definition 3 on the asset indexes in levels is relatively large. The farm asset index in column (1) is a count index of the types of farm equipment, out of a potential 13, that the household owns. The farm asset index increases by 0.6 among households administered Definition 3 . Since the average number of farm assets owned by households in the sample is 6.9 , the agricultural definition increased measured farm assets by

\footnotetext{
${ }^{18}$ Though, since only a tiny fraction of the sample ( 2.5 percent) is reported to have a woman as the head, this may be the result of the cultural practice of not reporting women as household heads even if a woman does, de facto, act as the head.

${ }^{19}$ Our adult equivalency scale uses the assumption that a child between the age of 0 and 5 consumes 0.4 of a full adult and children between 6 and 15 consume at 0.5 . Everyone over the age of 15 , including elderly, receive a value of 1 . The adult equivalency scale was adopted based on results in Deaton (1997). The results are very similar if we use per capita measures.
} 
approximately 10 percent or 0.3 of a standard deviation. Column (3) presents the effect of definition type on livestock holdings measured in tropical livestock units (TLUs), which is the number of animals owned by the household weighted by FAO TLU conversions. TLU livestock is higher among Definition 3 households compared with Definition 1 by 1.9 units or 0.2 of a standard deviation. Column (5) shows that the emphasis on common agriculture increased the number of nonfarm asset types owned by the household by 0.7 . The average number of asset types owned by the household is 12 , out of a possible 25; this constitutes 0.2 of a standard deviation change as well.

Including a common food requirement (Definition 2) also increases livestock holdings reported by the household, and there is weak evidence that reported farm assets also increased. The effects of Definition 2 are smaller ( 0.14 of a standard deviation) than those observed for Definition 3 for farm assets, but much larger than the effect of Definition 3 for livestock holdings. Definition 2 resulted in an economically meaningful 0.25 increase in a standard deviation of livestock holdings. This is consistent with the finding that Definition 3 increased the probability that at least one farmer resided in the household and Definition 2 increased the probability that a herder or fisherman was cited as a household member.20 As both Definitions 2 and 3 were shown to increase the number of married men (either son or brother of the head) listed in the household, these increases in asset holdings reported by the household are consistent with the findings in Table 2, even if household size does not increase significantly among the definitions. It is surprising that there is no difference in assets between Definition 4 and Definition 1 households, given changes in composition seen in Table 2 . Not only are the estimates not statistically significant but the point estimates are also small. The overall results illustrate that even if household sizes are consistent over time within a country, fluctuations observed in welfare levels may be driven by changes in household composition caused by altering household definitions or the administration of a particular definition over time.

Table 3. Assets

\begin{tabular}{|c|c|c|c|c|c|c|}
\hline & \multicolumn{2}{|c|}{ Farm assets } & \multicolumn{2}{|c|}{ Livestock (TLU) } & \multicolumn{2}{|c|}{ Assets, nonfarm } \\
\hline & (1) & (2) & (3) & (4) & $(5)$ & (6) \\
\hline & Levels & Per A.E. & Levels & Per A.E. & Levels & Per A.E. \\
\hline $\begin{array}{l}\text { Definition 2: common food, dwelling, } \\
\text { authority }\end{array}$ & $\begin{array}{r}0.272 * \\
(0.157)\end{array}$ & $\begin{array}{l}-0.039 \\
(0.041)\end{array}$ & $\begin{array}{l}2.652 * * * \\
(0.808)\end{array}$ & $\begin{array}{l}0.293 * * \\
(0.115)\end{array}$ & $\begin{array}{c}0.465 \\
(0.298)\end{array}$ & $\begin{array}{l}-0.069 \\
(0.071)\end{array}$ \\
\hline $\begin{array}{l}\text { Definition 3: common agriculture, } \\
\text { dwelling, authority }\end{array}$ & $\begin{array}{l}0.561 * * * \\
(0.157)\end{array}$ & $\begin{array}{l}-0.001 \\
(0.041)\end{array}$ & $\begin{array}{l}1.889^{* *} \\
(0.809)\end{array}$ & $\begin{array}{c}0.090 \\
(0.115)\end{array}$ & $\begin{array}{l}0.655^{* *} \\
(0.298)\end{array}$ & $\begin{array}{l}-0.094 \\
(0.071)\end{array}$ \\
\hline $\begin{array}{l}\text { Definition 4: common agriculture, } \\
\text { common food, dwelling, authority }\end{array}$ & $\begin{array}{l}0.166 \\
(0.157)\end{array}$ & $\begin{array}{l}-0.045 \\
(0.041)\end{array}$ & $\begin{array}{c}0.645 \\
(0.809)\end{array}$ & $\begin{array}{l}-0.035 \\
(0.115)\end{array}$ & $\begin{array}{c}0.254 \\
(0.298)\end{array}$ & $\begin{array}{l}-0.125^{*} \\
(0.071)\end{array}$ \\
\hline Constant & $\begin{array}{l}6.682 * * * \\
(0.111)\end{array}$ & $\begin{array}{l}0.976 * * * \\
(0.029)\end{array}$ & $\begin{array}{l}6.396^{* * *} \\
(0.570)\end{array}$ & $\begin{array}{l}0.916^{* * *} \\
(0.081)\end{array}$ & $\begin{array}{l}11.668 * * * \\
(0.210)\end{array}$ & $\begin{array}{l}1.704 * * * \\
(0.050)\end{array}$ \\
\hline $\begin{array}{l}\text { p-value: test of Definition } 2= \\
\text { Definition } 3\end{array}$ & 0.066 & & 0.346 & & 0.525 & \\
\hline $\begin{array}{l}\text { p-value: test of Definition } 3= \\
\text { Definition } 4\end{array}$ & 0.012 & & 0.126 & & 0.181 & \\
\hline $\begin{array}{l}\text { p-value: joint test of Definition } 2 \text {, } \\
\text { Definition } 3 \text {, and Definition } 4\end{array}$ & 0.004 & 0.563 & 0.005 & 0.021 & 0.149 & 0.346 \\
\hline $\mathrm{N}$ & 1,021 & 1,021 & 1,021 & 1,021 & 1,021 & 1,021 \\
\hline
\end{tabular}

Notes: The omitted definition is Definition 1: common dwelling and authority. The farm asset index in columns 1-2 is the number of equipment types, out of a potential 13, owned by the household. It is not the total number of farm assets as households were only asked if they owned one or more of each of the 13 tools. The tropical livestock units (TLUs) in columns 3-4 represent the number of animals owned by the household weighted according to FAO TLU conversions. Nonfarm assets, in columns 5-6, is an analogous measure to the farm asset index. Households were asked if they owned 25 different types of assets. All regressions include village fixed effects. A.E. $=$ adult equivalent. ${ }^{* * *} \mathrm{p}<0.01,{ }^{* *} \mathrm{p}<05,{ }^{*} \mathrm{p}<0.1$.

${ }^{20}$ There are few fishermen in the sample. 
Scaling our asset indices using the adult equivalency scale does not produce the same conclusions as the analysis in levels. We find no statistically significant effects of definition type on farm assets per adult equivalent, and the point estimates are quite small. TLUs per adult equivalent are still statistically significant, which is consistent with the results for TLUs in levels. Definition 2 leads to a 32-percent increase in per adult equivalent livestock relative to Definition 1 households. However, we find no effect of Definition 3 on TLUs. Definition 3 lowers the per adult equivalency nonfarm asset index by 12.5 percent, but given its marginal significance, we do not want to overinterpret this finding. Despite limited differences in per adult equivalent measures of assets, the effect of household definition on levels of assets is striking. Fluctuations in levels of assets measured using different household definitions do portray different profiles of households in terms of asset ownership or control of particular assets within the household.

\section{Food Consumption}

In Table 4, we again observe significant differences across definitions with respect to consumption reported by households. We present three measures of food consumption over the previous seven days, which are all related: a grain expenditure aggregate ${ }^{21}$ (in CFA francs [FCFA], ${ }^{22}$ the local currency), kilograms of all grain consumed, and finally kilograms of millet consumed. Millet is an important share of overall food consumption, and accounts for 69 percent of the total quantity of grain consumed by the households in our sample. Including keywords about common food requirements, as in Definition 2, increases the grain expenditure aggregate by 1,740 FCFA. The differences in statistics generated by Definition 3 that we have observed for other variables are absent with respect to household grain expenditure. However, the number of kilograms of grain consumed by the household over the previous seven days does increase significantly by including the common food requirement in Definition 2 or the common agriculture requirement in Definition 3. Definition 2 increases the reported kilograms of grain consumed by 9 kilograms, while the effect of Definition 3 is 8 kilograms. When we turn to the quantity of millet consumed, we find in column (5) that Definition 2 has the effect of raising the amount of millet consumed in the household by 7 kilograms.

These results are consistent with the explanation that variations in definitional keywords may drive variation in household statistics. Although we did not observe an increase in total household size for Definition 2, which includes common food requirements, we did observe changes in household structure (Table 2). By focusing definitional keywords on food consumption, we find that household consumption statistics are significantly larger in both aggregate and quantities of food reported in the consumption module. Differences in definitions have potential implications on poverty statistics. As budget shares of food compose the largest class of expenditures included in consumption aggregates, even small increases in expenditures and quantities of grain can produce large variation in consumption aggregates. However, in columns (2), (4), and (6) of Table 4, which report the results of the expenditure aggregate and grain consumed in per adult equivalents, we find no statistically significant effect of variations in definition type on consumption statistics, similar to results that we see in per adult equivalent measured asset indices.

\footnotetext{
${ }^{21}$ The grain expenditure aggregate scales purchased and own-food grain consumption over the last seven days at median village prices, following Deaton and Zaidi (2002).

${ }_{22}$ The exchange rate is currently 450 FCFA to the U.S. dollar.
} 


\begin{tabular}{|c|c|c|c|c|c|c|}
\hline & \multicolumn{2}{|c|}{$\begin{array}{l}\text { Grain expenditure } \\
\text { aggr egate (FCFA) }\end{array}$} & \multicolumn{2}{|c|}{$\begin{array}{l}\text { Kilograms of grains } \\
\text { consumed }\end{array}$} & \multicolumn{2}{|c|}{$\begin{array}{l}\text { Kilograms of millet } \\
\text { consumed }\end{array}$} \\
\hline & (1) & (2) & (3) & (4) & (5) & (6) \\
\hline & Levels & Per A.E. & Levels & Per A.E. & Levels & Per A.E. \\
\hline $\begin{array}{l}\text { Definition 2: common food, dwelling, } \\
\text { authority }\end{array}$ & $\begin{array}{c}1,740^{*} \\
(961)\end{array}$ & $\begin{array}{c}60.7 \\
(95.4)\end{array}$ & $\begin{array}{l}8.88 * * \\
(4.44)\end{array}$ & $\begin{array}{c}0.410 \\
(0.438)\end{array}$ & $\begin{array}{l}7.27 * * \\
(3.56)\end{array}$ & $\begin{array}{c}0.496 \\
(0.340)\end{array}$ \\
\hline $\begin{array}{l}\text { Definition 3: common agriculture, } \\
\text { dwelling, authority }\end{array}$ & $\begin{array}{c}1,580 \\
(962)\end{array}$ & $\begin{array}{l}49.0 \\
(95.5)\end{array}$ & $\begin{array}{c}7.66^{*} \\
(4.45)\end{array}$ & $\begin{array}{c}0.244 \\
(0.438)\end{array}$ & $\begin{array}{c}5.53 \\
(3.57)\end{array}$ & $\begin{array}{c}0.194 \\
(0.340)\end{array}$ \\
\hline $\begin{array}{l}\text { Definition 4: common agriculture, } \\
\text { common food, dwelling, authority }\end{array}$ & $\begin{array}{r}1,540 \\
(962)\end{array}$ & $\begin{array}{l}109.0 \\
(95.5)\end{array}$ & $\begin{array}{c}6.25 \\
(4.45)\end{array}$ & $\begin{array}{c}0.449 \\
(0.438)\end{array}$ & $\begin{array}{c}2.71 \\
(3.57)\end{array}$ & $\begin{array}{c}0.254 \\
(0.340)\end{array}$ \\
\hline Constant & $\begin{array}{l}10,100 * * * \\
(677)\end{array}$ & $\begin{array}{l}1,250.0 \\
(67.2)\end{array}$ & $\begin{array}{l}47.62^{* * * *} \\
(3.13)\end{array}$ & $\begin{array}{l}5.884^{* * * *} \\
(0.308)\end{array}$ & $\begin{array}{l}33.80 * * * \\
(2.51)\end{array}$ & $\begin{array}{l}4.100 * * * \\
(0.239)\end{array}$ \\
\hline $\begin{array}{l}\text { p-value: joint test of Definition } 2 \text {, } \\
\text { Definition 3, and Definition } 4\end{array}$ & 0.230 & 0.725 & 0.192 & 0.727 & 0.186 & 0.538 \\
\hline $\mathrm{N}$ & 1,011 & 1,011 & 1,011 & 1,011 & 1,011 & 1,011 \\
\hline
\end{tabular}

\section{Agricultural Production}

The last set of variables with which we investigate the implications of alternative household definitions are agricultural statistics, shown in Table 5. We calculate the number of plots and the value of agricultural production of grains in FCFA reported by the household over the last agricultural season, conditional on someone in the household undertaking farming in the last agricultural season in columns (1) through (4). Approximately 8 percent of the sample did not farm at all during the last season, reflective of the fact that pastoralism remains a main activity of some households in this geographic area. We analyze land size (columns [5] and [6]) and the total value of inputs, including seed, organic fertilizer, chemical fertilizer, and herbicide (columns [6] and [7]), both in levels and in per adult equivalent units. Table 5 illustrates that there are no statistically significant differences in the agricultural statistics for any of the definitions in levels. This may be because production statistics are reported at the plot level and reported landholdings are invariant to definition type, despite increases in the number of men reported in our household composition results. In the Segou region of Mali, the main agricultural work is done on communal family land where the family would include all married sons and married brothers of the household head. Therefore there may be little changes - or it may be difficult to detect relatively small changes - in production and inputs from the addition of one extra household member.

Although we observe no variation in agricultural statistics reported in levels, we observe a small reduction of the number of plots reported per adult equivalent by agricultural households in both Definitions 3 and 4. In fact, households that were presented with Definition 4 reported fewer plots and lower values of grain production (column [4]) and land size per adult equivalent. Definition 4 households report 22-percent lower per capita grain production values, or 0.2 of a standard deviation, than Definition 1 households.

In our empirical analysis, we find few effects on either the consumption or assets variables in per adult equivalent units. Production statistics, including number of plots, value of grain produced, and land size, in per adult equivalent units become smaller when further restrictions on household membership are imposed by the definition used. This is consistent with increasing numbers of men and women reported in Table 2. However, these results contrast with those found when analyzing consumption and asset indices in per adult equivalent units. In interpreting these results, it is difficult to precisely isolate whether increases in household size or composition drive the results. A priori, we expect increases in household size to reduce per adult equivalent statistics, but the effects of household composition are less 
straightforward. Our findings suggest that the reflection process through which respondents contemplate their responses may be quite different for consumption and asset questions compared to agricultural production. This may occur for a number of reasons, none of which is mutually exclusive. First, imperfect information among household members may affect accounting of consumption, assets holdings, and production. Consumption, in particular, is directly observed by all household members as households eat together communally. Asset holdings may also be readily observable by other household members as assets are often stored within the walls of the concession. However, agricultural production occurs outside of the household concession, by multiple decisionmakers on plots that are often not congruently located, which may increase informational asymmetries among household members. These information asymmetries could be further reinforced because consumption and agricultural production modules are normally administered to different respondents. This is particularly important if household definitions that emphasize different common activities — such as food consumption or agriculture - reveal different economic units. Information asymmetries may mean that the subsequent measures of household size, structure, consumption, and production may vary in levels or in per capita terms, depending on the information the respondent has about the activity in question. A second possibility arises because of differences in the recall periods in consumption, asset, and agricultural modules. Recall periods for food consumption follow the best practice of asking about food consumed over the previous 7 days, while agricultural production is recalled over the previous agricultural season, which may span the previous year. Asset holdings are recalled based on current possession of an item. These differences in recall periods may reduce the reliability of agricultural data relative to the consumption and asset data as posited in the recall bias literature (Beckett et al. 2001). 
Table 5. Agricultural production and inputs

\begin{tabular}{|c|c|c|c|c|c|c|c|c|}
\hline & \multicolumn{2}{|c|}{$\begin{array}{l}\text { Number of plots } \\
\text { conditional on } \\
\text { household farming }\end{array}$} & \multicolumn{2}{|c|}{$\begin{array}{l}\text { Value of grains produced } \\
\text { (FCFA) conditional on } \\
\text { household farming }\end{array}$} & \multicolumn{2}{|c|}{$\begin{array}{l}\text { Land size } \\
\text { (hectares) }\end{array}$} & \multicolumn{2}{|c|}{ Total plot inputs } \\
\hline & $(1)$ & $(2)$ & (3) & (4) & $(5)$ & $(6)$ & (7) & $(8)$ \\
\hline & Levels & Per A.E. & Levels & Per A.E. & Levels & Per A.E. & Levels & Per A.E. \\
\hline Definition 2: common food, dwelling, authority & $\begin{array}{c}0.109 \\
(0.105)\end{array}$ & $\begin{array}{l}-0.009 \\
(0.015)\end{array}$ & $\begin{array}{c}6,663 \\
(76,436)\end{array}$ & $\begin{array}{l}-4,470 \\
(8,479)\end{array}$ & $\begin{array}{l}-0.150 \\
(0.606)\end{array}$ & $\begin{array}{l}-0.061 \\
(0.069)\end{array}$ & $\begin{array}{c}58,348 \\
(66,624)\end{array}$ & $\begin{array}{c}3,499 \\
(5,257)\end{array}$ \\
\hline Definition 3: common agriculture, dwelling, authority & $\begin{array}{l}-0.016 \\
(0.105)\end{array}$ & $\begin{array}{l}-0.028^{*} \\
(0.015)\end{array}$ & $\begin{array}{c}-840 \\
(75,958)\end{array}$ & $\begin{array}{l}-7,859 \\
(8,425)\end{array}$ & $\begin{array}{c}0.149 \\
(0.606)\end{array}$ & $\begin{array}{l}-0.055 \\
(0.069)\end{array}$ & $\begin{array}{c}72,197 \\
(66,706)\end{array}$ & $\begin{array}{c}4,200 \\
(5,263)\end{array}$ \\
\hline $\begin{array}{l}\text { Definition } 4 \text { : common agriculture, common food, dwelling, } \\
\text { authority }\end{array}$ & $\begin{array}{l}-0.028 \\
(0.105)\end{array}$ & $\begin{array}{l}-0.028^{*} \\
(0.015)\end{array}$ & $\begin{array}{l}-92,188 \\
(76,012)\end{array}$ & $\begin{array}{l}-20,917 * * \\
(8,431)\end{array}$ & $\begin{array}{l}-0.388 \\
(0.606)\end{array}$ & $\begin{array}{l}-0.121^{*} \\
(0.069)\end{array}$ & $\begin{array}{c}11,922 \\
(66,710)\end{array}$ & $\begin{array}{c}-513 \\
(5,264)\end{array}$ \\
\hline Constant & $\begin{array}{l}2.041^{* * *} \\
(0.075)\end{array}$ & $\begin{array}{l}0.284^{* * *} \\
(0.011)\end{array}$ & $\begin{array}{l}801,703 * * * \\
(53,981)\end{array}$ & $\begin{array}{l}96,037 * * * \\
(5,988)\end{array}$ & $\begin{array}{l}6.726^{* * *} \\
(0.428)\end{array}$ & $\begin{array}{l}0.843 * * * \\
(0.048)\end{array}$ & $\begin{array}{l}199,881 * * * \\
(47,033)\end{array}$ & $\begin{array}{l}22,483 * * * \\
(3,711)\end{array}$ \\
\hline p-value: joint test of Definition 2, Definition 3, and Definition 4 & 0.541 & 0.175 & 0.508 & 0.078 & 0.837 & 0.379 & 0.647 & 0.743 \\
\hline $\mathrm{N}$ & 937 & 937 & 926 & 926 & 1,021 & 1,021 & 1,021 & 1,021 \\
\hline
\end{tabular}




\section{CONCLUSION}

In this paper, we present the results of a survey experiment designed to measure the consequences of altering the definition of the household on a wide range of measures frequently collected in multi-topic household surveys. Despite the fundamental importance of the unit of analysis in any type of research, the "household" remains something of a black box for economists. Efforts to standardize the definition using the commonly accepted "common pot" definition still meet operational complications in the field as noted by Udry (1996). Variation in household definition is common among surveys fielded within countries and between countries, yet we know little about the consequences of alternative definition types on key household statistics.

Our results tell a cautionary tale, suggesting that the selection of the household definition deserves more attention in the design of future surveys and the analysis of previously collected surveys. We assumed that including additional keywords and criteria in our definitions would impose a logical consistency on the subset of household members that were generated by these definitions, with households assigned definitions with more criteria for membership producing smaller household units. What we observed from this experiment is that definitional criteria intended to produce this consistency increased household size in some cases and always altered household composition, which had implications for household-level consumption and asset statistics and per adult equivalent agricultural production measures in particular. This may be because the keywords prompt respondents to remember individuals who would otherwise be forgotten and/or because the keywords change the concept of the household and prompt a different set of individuals to be reported as the "household." Variation in composition was driven mainly by the inclusion or exclusion of adult men and women among the alternative household definitions tested. Hence, even when definitions did not change household size, the relevant economic unit measured differed across definition type.

Although variation in the household definition did not in every case affect household or per adult equivalent statistics, variation in assets, livestock holdings, and grain consumption is striking and economically meaningful. Since food expenditure composes 50 to 80 percent of a household's budget share (Seale, Regmi, and Bernstein 2003; Banerjee and Duflo 2007), our findings on grain consumption and the variation that different definition types may have on poverty statistics merit further investigation, especially in the context of cross-country or panel analysis.

The results from this survey experiment suggest two potentially conflicting implications for the collection of household survey data. First, a consistent household definition is required in order to make comparisons over time in a given population and across populations. Second, over time for a given population, the definition must also identify the correct economic or decisionmaking unit, which may, in fact, differ according to the research question. Therefore, it is difficult to prescribe "best practice," given these two competing objectives. On the one hand, using a common definition is paramount for comparability across datasets, but on the other, researchers may need to alter the definition used in a particular survey to cater to the specific research questions under study. The latter creates difficulties in evaluating the external validity of particular studies or the aggregation of multiple household surveys for cross-country analysis.

Why might we want to tailor the household definition to the needs of a given study? First, in order to identify the relevant economic unit: for example, a study focused on agricultural input use, such as fertilizer, may want a definition that emphasizes an economic production unit that farms together. Accordingly, this study is also relevant for the growing number of field experiments seeking to identify the causal effect of a program on household welfare or other outcomes across populations. Since the choice of the household definition affects which people are grouped together into a household, it is necessary for the household definition used in data collection to correspond to the relevant group of people affected by a program. Household definitions that group the "wrong" set of people together reduce the likelihood that a program impact is detectable. In addition, important spillovers may be missed if benefits are spread across individuals who are allocated into separate households - some designated as 
control and others as treatment. In an environment where the group of people who undertake joint agricultural activities may differ from the group that undertakes common food consumption, the research must identify the right group in order to look at the impact of a program on agricultural income and/or food consumption.

Second, since we often assume that all household members have access to public goods within the household, the household definition capturing the "wrong group" would then erroneously ascribe userights over assets to some individuals and exclude others. Accurate estimates of household size or asset holdings are important in and of themselves as policy tools to measure welfare and potentially target government or nongovernmental organization's interventions, but these measurement issues are also fundamental to the estimation of economic relationships.

This study shows that in one part of one developing country, changes in the definition of the household altered household and per adult equivalency statistics that are frequently collected in multitopic household surveys. Future research is required to understand how other variations in household definitions, including alternative definition types and definition phrasing, can alter how individuals are grouped into households and the resulting measures of household and individual welfare, and whether the household definition remains an important issue in contexts other than Mali where the concept of the household may be clearer. 


\section{APPENDIX: SUPPLEMENTARY TABLE}

Table A.1. Descriptive statistics

\begin{tabular}{|c|c|c|c|c|c|c|}
\hline & & \multicolumn{4}{|c|}{ Definition: } & \multirow[b]{2}{*}{ Total } \\
\hline & & 1 & 2 & 3 & 4 & \\
\hline \multicolumn{7}{|l|}{ Household composition } \\
\hline Household size of 6-month residents & $\begin{array}{l}\text { Mean } \\
\text { Standard Deviation }\end{array}$ & $\begin{array}{c}11 \\
(5.7)\end{array}$ & $\begin{array}{l}11.8 \\
(6.3)\end{array}$ & $\begin{array}{l}12.1 \\
(6.6)\end{array}$ & $\begin{array}{l}11.7 \\
(5.4)\end{array}$ & $\begin{array}{l}11.6 \\
(6.0)\end{array}$ \\
\hline Number of males listed & $\begin{array}{l}\text { Mean } \\
\text { Standard Deviation }\end{array}$ & $\begin{array}{c}5.7 \\
(3.1)\end{array}$ & $\begin{array}{c}6.2 \\
(3.4)\end{array}$ & $\begin{array}{c}6.3 \\
(3.6)\end{array}$ & $\begin{array}{c}6.1 \\
(3.1)\end{array}$ & $\begin{array}{c}6.1 \\
(3.4)\end{array}$ \\
\hline Number of females listed & $\begin{array}{l}\text { Mean } \\
\text { Standard Deviation }\end{array}$ & $\begin{array}{c}5.4 \\
(3.4)\end{array}$ & $\begin{array}{c}5.6 \\
(3.5)\end{array}$ & $\begin{array}{c}5.8 \\
(3.6)\end{array}$ & $\begin{array}{l}5.6 \\
(2.9)\end{array}$ & $\begin{array}{c}5.6 \\
(3.4)\end{array}$ \\
\hline \multicolumn{7}{|l|}{ Assets } \\
\hline Farm asset index & $\begin{array}{l}\text { Mean } \\
\text { Standard Deviation }\end{array}$ & $\begin{array}{c}6.7 \\
(1.9)\end{array}$ & $\begin{array}{c}6.9 \\
(1.9)\end{array}$ & $\begin{array}{l}7.3 \\
(2.2)\end{array}$ & $\begin{array}{c}6.8 \\
(1.7)\end{array}$ & $\begin{array}{c}6.9 \\
(1.9)\end{array}$ \\
\hline Livestock (tropical livestock units) & $\begin{array}{l}\text { Mean } \\
\text { Standard Deviation }\end{array}$ & $\begin{array}{c}6.4 \\
(8.4)\end{array}$ & $\begin{array}{c}9.1 \\
(12.8)\end{array}$ & $\begin{array}{c}8.2 \\
(10.4)\end{array}$ & $\begin{array}{c}7 \\
(9.3)\end{array}$ & $\begin{array}{c}7.7 \\
(10.4)\end{array}$ \\
\hline Nonfarm asset index & $\begin{array}{l}\text { Mean } \\
\text { Standard Deviation }\end{array}$ & $\begin{array}{l}11.7 \\
(3.9)\end{array}$ & $\begin{array}{l}12.1 \\
(3.8)\end{array}$ & $\begin{array}{l}12.3 \\
(3.7)\end{array}$ & $\begin{array}{l}11.9 \\
(3.6)\end{array}$ & $\begin{array}{c}12 \\
(3.7)\end{array}$ \\
\hline \multicolumn{7}{|l|}{ Consumption statistics (previous 7 days) } \\
\hline Kilograms of grains consumed & $\begin{array}{l}\text { Mean } \\
\text { Standard Deviation }\end{array}$ & $\begin{array}{c}47.5 \\
(43.5)\end{array}$ & $\begin{array}{c}56.6 \\
(60.1)\end{array}$ & $\begin{array}{c}55.3 \\
(47.8)\end{array}$ & $\begin{array}{c}53.8 \\
(52.1)\end{array}$ & $\begin{array}{c}53.3 \\
(51.3)\end{array}$ \\
\hline Grain expenditure (CFA francs) & $\begin{array}{l}\text { Mean } \\
\text { Standard Deviation }\end{array}$ & $\begin{array}{c}10,092 \\
(9,095.0)\end{array}$ & $\begin{array}{c}11,861 \\
(12,455.0)\end{array}$ & $\begin{array}{c}11,698 \\
(10,556.0)\end{array}$ & $\begin{array}{c}11,645 \\
(12,419.0)\end{array}$ & $\begin{array}{c}11,319 \\
(11,219.0)\end{array}$ \\
\hline \multicolumn{7}{|l|}{ Agricultural statistics } \\
\hline Value of grain produced (CFA francs) & $\begin{array}{l}\text { Mean } \\
\text { Standard Deviation }\end{array}$ & $\begin{array}{c}794,726 \\
(1,118,141)\end{array}$ & $\begin{array}{c}974,737 \\
(2,353,717)\end{array}$ & $\begin{array}{c}752,029 \\
(944,861)\end{array}$ & $\begin{array}{c}735,976 \\
(1,138,551)\end{array}$ & $\begin{array}{c}814,623 \\
(1,500,268)\end{array}$ \\
\hline Land cultivated (hectares) & $\begin{array}{l}\text { Mean } \\
\text { Standard Deviation }\end{array}$ & $\begin{array}{c}6.7 \\
(8.8)\end{array}$ & $\begin{array}{c}6.7 \\
(7.6)\end{array}$ & $\begin{array}{c}7.1 \\
(8.3)\end{array}$ & $\begin{array}{c}6.5 \\
(7.3)\end{array}$ & $\begin{array}{c}6.7 \\
(8.0)\end{array}$ \\
\hline Input value (CFA francs) & $\begin{array}{l}\text { Mean } \\
\text { Standard Deviation }\end{array}$ & $\begin{array}{c}198,550 \\
(410,547)\end{array}$ & $\begin{array}{c}257,494 \\
(596,547)\end{array}$ & $\begin{array}{c}273,080 \\
(1,449,147)\end{array}$ & $\begin{array}{c}212,890 \\
(456,825)\end{array}$ & $\begin{array}{c}235,438 \\
(839,563)\end{array}$ \\
\hline $\mathrm{N}$ & & 257 & 256 & 254 & 254 & 1,021 \\
\hline
\end{tabular}




\section{REFERENCES}

Akresh, R. 2009. Flexibility of household structure: Child fostering decisions in Burkina Faso. Journal of Human Resources 44 (4): 976-997.

Banerjee, A., and E. Duflo. 2007. The economic lives of the poor. Journal of Economic Perspectives 21 (1): 141-168.

Beckett, M., J. DaVanzo, N. Sastry, C. Panis, and C. Peterson. 2001. The quality of retrospective data: An examination of long-term recall in a developing country. Journal of Human Resources 36 (3): 593-625.

Bryant, J. 1996. Northern Vietnamese households. Journal of Population Research 13 (2): 169-186.

Christiaensen, L., and J. Hoddinott. 2001. Comparing village characteristics derived from rapid appraisals and household surveys: A tale of northern Mali. Journal of Development Studies 37 (3): 1-20.

Deaton, A. 1997. The analysis of household surveys. Baltimore, Md., U.S.A.: John Hopkins University Press.

Deaton, A., and S. Zaidi. 2002. Guidelines for constructing consumption aggregates for welfare analysis. Living Standards Measurement Stidu Working Paper No. 135. Washington, D.C.: World Bank. < http://wwwwds.worldbank.org/external/default/WDSContentServer/WDSP/IB/2002/07/31/000094946_020713040105 52/Rendered/PDF/multi0page.pdf >. Accessed June 16, 2010.

Glewwe, P., and M. Grosh, eds. 2000. Designing household survey questionnaires for developing countries: Lessons from 15 years of the Living Standards Development Study. Washington, D.C.: Oxford University Press (for the World Bank). Quoting United Nations, Household income and expenditure surveys: A technical study (New York: National Household Survey Capability Program, 1989).

Guyer, J. 1981. Household and community in African studies. African Studies Review 24 (2/3): 87-128.

Hill, P. 1986. Development economics on trial: The anthropological case for prosecution. Cambridge: Cambridge University Press.

Hosegood, V., and I. M. Timaeus. 2005. Household composition and dynamics in KwaZulu Natal, South Africa: Mirroring social reality in longitudinal data collection. In African households: Censuses and surveys, ed. E. Van de Walle, 58-77. Armonk, N.Y., U.S.A.: M. E. Sharpe.

Leone, T., E. Coast, and S. Randall. 2009. Did you sleep here last night? The impact of the household definition in sample surveys: A Tanzanian case study. Presentation at British Society for Population Studies annual conference, September 9-11, Brighton, U.K.

Mali, Republic of. 1999. Cartographie du Mali 1998. UNICEF and Fox Media.

. 2006. Recensement général de l'agriculture (RGA) - Campagne agricole 2004-2005 Résultats définitifs-Volume 1 Rapport de synthèse. Food and Agriculture Organization of the United Nations, Coopération Française. Photocopy.

. 2007. Enquete legere integree aupres des menages (elim) 2006. Vol. 1-3. World Bank, European Union. Photocopy.

Matlon, P. J. 1988. The ICRISAT Burkina Faso farm level studies: Survey methods and data files. Village Level Studies Miscellaneous Papers Series, Economics Group. Hyderabad, India: International Crops Research Institute for the Semi-Arid Tropics (ICRISAT). Quoted in Udry, C., Gender, agricultural production, and the theory of the household, Journal of Political Economy 104, no. 5 (1996): 1010-1046.

Muga, G. O., and W. Onyango-Ouma. 2009. Changing household composition and food security among the elderly caretakers in rural western Kenya. Journal of Cross-Cultural Gerontology 24: 259-272.

Ruggles, S., and M. Heggeness. 2008. Intergenerational coresidence in developing countries. Population and Development Review 34 (2): 253-281.

Saito, O. 2000. Marriage, family labour, and the stem family household: Traditional Japan in a comparative perspective. Continuity and Change 15 (1): 17-45. 
Samaké, S., S. Traoré, S. Ba, E. Dembélé, M. Diop, S. Mariko, and P. Libité. 2007. Enquête démographique et de santé du Mali 2006. Full report. Macro International, Calverton, Md., U.S.A. Photocopy.

Seale, Jr., J., A. Regmi, and J. Bernstein. 2003. International evidence on food consumption patterns. USDA Economic Research Service Technical Bulletin Number 1904. Washington, D.C.: U.S. Department of Agriculture. $<$ http://www.ers.usda.gov/publications/tb1904/tb1904.pdf $>$. Accessed June 16, 2010.

Udry, C. 1990. Credit markets in northern Nigeria: Credit as insurance in a rural economy. World Bank Economic Review 4 (3): 251-269.

. 1996. Gender, agricultural production, and the theory of the household. Journal of Political Economy 104 (5): 1010-1046.

Van de Walle, E., and A. Gaye. 2005. Household structure, polygyny, and ethnicity in Senegambia: A comparison of census methodologies. In African households: Censuses and surveys, ed. E. Van de Walle, 3-21. Armonk, N.Y., U.S.A.: M. E. Sharpe.

Vimard, P., and R. Fassassi. 2005. The family at the heart of the household: Evolution and differentiation of household structure in Côte d'Ivoire, 1975-98. In African households: Censuses and surveys, ed. E. Van de Walle, 102-128. Armonk, N.Y.: M. E. Sharpe. 


\section{RECENT IFPRI DISCUSSION PAPERS}

\section{For earlier discussion papers, please go to www.ifpri.org/pubs/pubs.htm\#dp. All discussion papers can be downloaded free of charge.}

1008. Livestock development planning in Uganda: Identification of areas of opportunity and challenge. Todd Benson and Samuel Mugarura. 2010.

1007. Migratory responses to agricultural risk in northern Nigeria. Andrew Dillion, Valerie Mueller, and Sheu Salau. 2010.

1006. Do comprehensive Africa agriculture development program (CAADP) processes make a difference to country commitments to develop agriculture?: The case of Ghana. Shashidhara Kolavalli, Kathleen Flaherty, Ramatu Al-Hassan, and Kwaku Owusu Baah, 2010.

1005. The new Nicaraguan water law in context: Institutions and challenges for water management and governance. Paula Novo and Alberto Garrido, 2010.

1004. Potential of carbon markets for small farmers: A literature review. Alessandro De Pinto, Marilia Magalhaes, and Claudia Ringler, 2010.

1003. Understanding gender differences in agricultural productivity in Uganda and Nigeria. Amber Peterman, Agnes Quisumbing, Julia Behrman, and Ephraim Nkonya, 2010.

1002. Old problems in the new solutions? Politically motivated allocation of program benefits and the "new" fertilizer subsidies. Afua Branoah Banful, 2010.

1001. The role of public-private partnerships in promoting smallholder access to livestock markets in developing countries: methodology and case studies. Karl M. Rich and Clare A. Narrod, 2010.

1000. Mapping the policy process in Nigeria: Examining linkages between research and policy. Noora-Lisa Aberman, Eva Schiffer, Michael Johnson, and Victor Oboh, 2010.

999. Sales location and supply response among semisubsistence farmers in Benin: A heteroskedastic double selection model. Hiroyuki Takeshima and Alex Winter-Nelson, 2010.

998. A review of collective action in rural Ghana. Adam Salifu, Gian Nicola Francesconi, and Shashidhara Kolavalli, 2010.

997. Eight years of Doha trade talks: Where do we stand? Antoine Bouet and David Laborde Debucquet, 2010.

996. Price, inventories, and volatility in the global wheat Market. Kyösti Pietola, Xing Liu, and Miguel Robles, 2010.

995. Access, adoption, and diffusion: Understanding the long-term impacts of improved vegetable and fish technologies in Bangladesh. Neha Kumar and Agnes R. Quisumbing, 2010.

994. Economics of export taxation in a context of food crisis: A theoretical and CGE approach contribution. Antoine Bouët and David Laborde Debucquet, 2010.

993. What is the irrigation potential for Africa? A combined biophysical and socioeconomic approach. Liangzhi You, Claudia Ringler, Gerald Nelson, Ulrike Wood-Sichra, Richard Robertson, Stanley Wood, Zhe Guo, Tingju Zhu, and Yan Sun, 2010 .

992. Impact of farmer field schools on agricultural productivity and poverty in East Africa. Kristin Davis, Ephraim Nkonya, Edward Kato, Daniel Ayalew Mekonnen, Martins Odendo, Richard Miiro, and Jackson Nkuba, 2010.

991. Exploring the long-term impact of development interventions within life-history narratives in rural Bangladesh. Peter Davis, 2010.

990. The costs and benefits of duty-free, quota-free market access for poor countries: Who and what matters? Antoine Bouët, David Laborde Debucquet, Elisa Dienesch, and Kimberly Elliot, 2010.

989. Mountains, global food prices, and food security in the developing world. Kamiljon T. Akramov, Bingxin Yu, and Shenggen Fan, 2010.

988. Examining the dynamic relationship between spot and future prices of agricultural commodities. Manuel Hernandez and Maximo Torero, 2010.

987. Dynamic agricultural supply response under economic transformation: A case study of Henan Province. Bingxin Yu, Fengwei Liu, and Liangzhi You, 2010. 




\section{INTERNATIONAL FOOD POLICY RESEARCH INSTITUTE}

\section{www.ifpri.org}

IFPRI HEADQUARTERS

2033 K Street, NW

Washington, DC 20006-1002 USA

Tel.: +1-202-862-5600

Fax: +1-202-467-4439

Email: ifpri@cgiar.org

IFPRI ADDIS ABABA

P. O. Box 5689

Addis Ababa, Ethiopia

Tel.: +251116463215

Fax: +251116462927

Email: ifpri-addisababa@cgiar.org

IFPRI NEW DELHI

CG Block, NASC Complex, PUSA

New Delhi 110-012 India

Tel.: 9111 2584-6565

Fax: 9111 2584-8008 / 2584-6572

Email: ifpri-newdelhi@cgiar.org 